\title{
Population-Based Epidemiology Study of Paraneoplastic Neurologic Syndromes
}

\author{
Shailee Shah, MD, Eoin P. Flanagan, MBBCh, Pritikanta Paul, MD, Carin Y. Smith, BS, Sandra C. Bryant, MS, \\ Michelle F. Devine, MD, Vanda A. Lennon, MD, PhD, Andrew McKeon, MD, Sean J. Pittock, MD, and \\ Divyanshu Dubey, MD
}

Neurol Neuroimmunol Neuroinflamm 2022;9:e1124. doi:10.1212/NXI.0000000000001124

\author{
Correspondence \\ Dr. Dubey \\ dubey.divyanshu@mayo.edu
}

\begin{abstract}
\section{Objectives}

Population-based epidemiologic data for paraneoplastic neurologic syndromes (PNSs) in the United States are lacking. Our objective was to evaluate the incidence, prevalence, and associated morbidity of PNS.
\end{abstract}

\section{Methods}

We performed a population-based epidemiology study in Olmsted County, Minnesota, with patients identified between January 1, 1987, and December 31, 2018, using the medical records linkage system of the Rochester Epidemiology Project (REP) who met the definite/probable 2021 PNS criteria and 2004 PNS criteria. Patients with dermatomyositis and myasthenia gravis with underlying tumors were included. Age- and sex-specific population counts were obtained from REP resources for January 1, 2014 (prevalence denominator) and annually for 1987-2018 (incidence denominator). Morbidity was estimated using disability-adjusted life years (DALYs; years lived with disability [YLD] plus years of life lost [YLL]).

\section{Results}

There were 28 patients with PNS identified (50\% female) residing in Olmsted County, Minnesota, with median age at diagnosis of 54.5 (IQR 46.5-69.0) years. All patients had a cancer diagnosis, and $18(64 \%)$ patients were neural autoantibody positive including antineuronal nuclear autoantibody type 1 (ANNA-1/anti-Hu; $\mathrm{n}=1$ ), ANNA-2/anti-Ri $(\mathrm{n}=1)$, muscle-type acetylcholine receptor (AChR; $n=6$ ), Purkinje cell cytoplasmic antibody type 1 (PCA-1/anti-Yo; $\mathrm{n}=1)$, kelch-like protein $11(\mathrm{KLH} 11 ; \mathrm{n}=3)$, collapsin response mediator protein 5 (CRMP-5/ anti-CV2; $\mathrm{n}=2)$, $\alpha$-amino-3-hydroxy-5-methyl-4-isoxazole propionic acid receptor $(\mathrm{n}=1)$, neurofilament light chain $(\mathrm{n}=1)$, leucine zipper 4 (LUZP4; $\mathrm{n}=1$ ), and unclassified neural antibodies $(\mathrm{n}=1)$. PNS incidence was $0.6 / 100,000$ person-years and increased over time from $0.4 / 100,000$ person-years $(1987-2002)$ to $0.8 / 100,000$ person-years $(2003-2018)(p=0.06)$. Prevalence was 5.4/100,000 people. The median follow-up period after PNS diagnosis was 3.1 years (IQR, 1.1-9.9 years). Total disability-adjusted life years (DALYs) for 28 patients with PNS were 472.7 years, based on total years of life lost (YLL) for patients dying between 1987 and 2018 $(n=15)$ of 445.3 years plus years lived with disability (YLD) 27.4 years.

\section{Discussion}

PNSs are rare neurologic disorders but are associated with severe morbidity and mortality. The estimated number of prevalent PNS cases in the United States is 17,099, and predicted DALY for all US PNS cases is 292,393 years. Their apparent increasing rate of detection is attributable to increasing physician awareness and availability of serologic testing. 


\section{Glossary}

DALY = disability-adjusted life year; GBD = Global Burden of Disease; LUZP4 = leucine zipper 4; PNS = paraneoplastic neurologic syndrome; REP = Rochester Epidemiology Project; YLD = years lived with disability; YLL = years of life lost.

Paraneoplastic neurologic syndromes (PNSs) reflect immune responses (antibody or $\mathrm{T}$ cell mediated) against neural antigens expressed by an underlying, often unsuspected, tumor which when recognized early are amenable to treatment with immunotherapy along with tumor treatment. ${ }^{1}$ Epidemiologic data for PNS have been reported from Europe but are lacking for the United States, despite the growing recognition of these disorders and advances in test methodology. ${ }^{2,3}$ Our primary objective is to report the incidence and prevalence of PNS in Olmsted County, Minnesota, a geographically defined region of the United States. We also aim to estimate the morbidity and mortality of PNS using the World Health Organization (WHO) Global Burden of Disease (GBD) disability metric disability-adjusted life years (DALYs).

\section{Methods}

\section{Standard Protocol Approvals, Registrations, and Patient Consents}

The study was approved by the Institutional Review Boards of Mayo Clinic and Olmsted Medical Center. All patients provided consent to research use of their medical records.
The records linkage system of the Rochester Epidemiology Project (REP, representing all medical practitioners in Olmsted County) enabled a population-based calculation of PNS incidence and prevalence among residents of Olmsted County, Minnesota. We identified patients with diagnostic codes pertaining to PNS as noted in Figure 1 and applied diagnostic criteria to define prevalent cases as of January 1, 2014, and incident cases between January 1, 1987, and December 31, 2018. The population of Olmsted County, in southeastern Minnesota, was 155,285 (January 1, 2014, including the city of Rochester) and is predominantly of northern European descent. The REP records linkage system captures all patients receiving care from local health care providers, and the coverage is nearly $100 \%$ in comparison to the US census estimates. ${ }^{4}$ Further REP characteristics are described elsewhere. ${ }^{4-6}$

\section{Autoantibody Detection}

Eleven frozen archival samples (1987-2014) of patients with a diagnosis of PNS identified through medical record review as described above were retested for more recently recognized autoantibodies. All testing was otherwise historically performed in the Mayo Clinic Neuroimmunology Laboratory by

Figure 1 Flowchart of Patient Identification, Inclusion and Exclusion, and Number of Incident and Prevalent Paraneoplastic Neurologic Syndrome (PNS) Cases

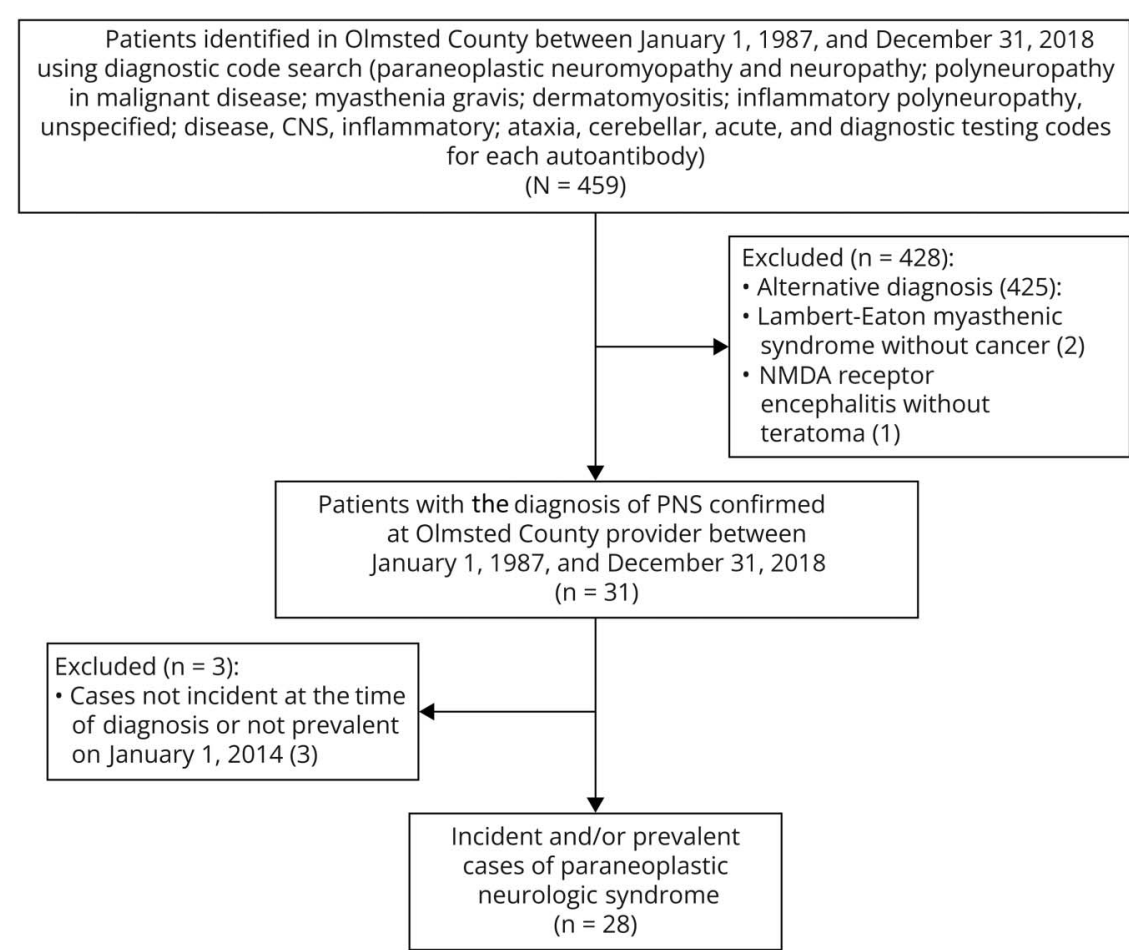

Included patients met 2021 PNS criteria with PNSCare score $>6$, and/or 2004 PNS criteria, or had paraneoplastic myasthenia gravis (cancer detected within 2 years of neurologic symptom onset). 
standardized methodologies and was available through the medical records. ${ }^{7,8}$

\section{Diagnostic Criteria}

The included patients met definite or probable 2021 PNS-Care criteria (score $\geq 6$ ), a recently developed tool for identifying paraneoplastic disease based on the 2021 updated PNS criteria, created due to identification of new phenotypes and autoantibodies in the past 20 years. The PNS-Care scores combine: the risk associated with specific clinical phenotypes previously defined as classical or nonclassical now categorized as high risk or intermediate risk based on expert consensus recognition of highly pathognomonic phenotypes (i.e., encephalomyelitis, limbic encephalitis, and sensory neuronopathy, among others), the presence of onconeural antibodies now more granularly categorized as high ( $>70 \%$ associated with cancer), medium (30\%-70\% associated with cancer), and low (<30\%) risk, and cancer consistent with the antibody found within 1 or 2 years of presentation. ${ }^{9}$ Given that validation of the PNS-Care score has not yet been performed, the patients included in the final cohort also met the 2004 PNS criteria as follows: 1) a classical syndrome with development of cancer (including thymomatous cancers) within 2 years of diagnosis, 2) a nonclassical syndrome within 2 years of cancer diagnosis and either the detection of an onconeural autoantibody (including novel specificities not yet reported) or significant neurologic improvement after cancer treatment, or 3) a classical or nonclassical syndrome and detection of a well-characterized onconeural autoantibody. Patients with dermatomyositis and myasthenia gravis with underlying tumors were included. ${ }^{10}$ Patients with Lambert-Eaton myasthenic syndrome $(\mathrm{n}=2)$ and NMDA receptor encephalitis $(\mathrm{n}=1)$ without underlying malignancy were excluded as they did not meet the PNS-Care criteria for definite or probable PNS at long-term follow-up greater than 2 years. Clinical syndromes, their associated cancers, their autoantibody seropositivity, and their classification into either the 2004 Paraneoplastic Neurological Syndrome Classification or 2021 Paraneoplastic Neurological Syndrome Care Score are summarized in Table 1.

\section{Statistical Analysis}

Age- and sex-specific population counts for Olmsted County were obtained from the REP census data for January 1, 2014 (prevalence denominator, per 100,000 people) and annually for 1987-2018 (incidence denominator). Incidence rates were calculated for 1987-2002, 2002-2018, and 1987-2018 using total number of person-years at risk per 100,000 person-years and directly adjusted to the age and sex distribution of the 2010 US census. CIs were not reported because the Olmsted County population is completely enumerated (no sampling was involved). Age-adjusted and sex-adjusted Poisson regression models were used to compare incidence rates across 2 time periods.

Morbidity and mortality were estimated using a hybrid model of disability-adjusted life years (DALYs), calculated as the summation of incidence-based years of life lost (YLL) and prevalence-based years lived with disability (YLDs). ${ }^{11}$ YLL was defined as the standard expected years of life lost based on the age at death from the World Health Organization Global Burden of Disease. ${ }^{10}$ Using extensive population-based survey data, GBD has provided nonfatal burden estimates including disability weights for neurologic conditions categorized as mild, moderate, and severe motor impairment, motor plus cognitive impairment, and long-term nerve injury, which were applied to individuals in our PNS cohort. ${ }^{12,13}$ For each patient in the cohort, YLD was defined as the cumulative years from neurologic syndrome onset to death, last follow-up, or end of the study period (December 31, 2018) multiplied by the assigned disability weight. ${ }^{11}$ Statistical analysis used SAS version 9.4.

\section{Data Availability}

Data not provided in the article because of space limitations may be shared (anonymized) at the request of any qualified investigator for purposes of replicating procedures and results.

\section{Results}

Twenty-eight patients were identified ( $50 \%$ female); median age was 54.5 (IQR, 46.5-69.0) years; reported ethnicities were non-Hispanic White $(\mathrm{n}=24)$, Asian $(\mathrm{n}=1)$, Black $(\mathrm{n}=2)$, and Hispanic $(n=1)$. Most common cancer diagnoses were thymoma/thymic carcinoma $(n=6,21 \%)$, breast adenocarcinoma $(n=4,14 \%)$, seminoma $(n=4,14 \%)$, and small-cell lung carcinoma $(n=4,14 \%)$. Eighteen patients $(64 \%)$ were neural autoantibody positive: antineuronal nuclear autoantibody type 1 (ANNA-1/anti-Hu; $\mathrm{n}=1)$, ANNA-2/anti-Ri $(\mathrm{n}=1)$, muscle-type acetylcholine receptor $(\mathrm{AChR} ; \mathrm{n}=6)$, Purkinje cell cytoplasmic antibody type 1 (PCA-1/anti-Yo; $n=1$ ), kelch-like protein $11(\mathrm{KLH} 11 ; \mathrm{n}=3$; all with coexisting leucine zipper 4 [LUZP4] autoantibodies), collapsin response mediator protein 5 (CRMP-5/anti-CV2; $n=2 ; n=1$ with coexisting neural antibodies to leucine-rich glioma-inactivated protein 1 and glutamic acid decarboxylase titer $60 \mathrm{nmol} / \mathrm{L}$ ), $\alpha$-amino-3hydroxy-5-methyl-4-isoxazole propionic acid receptor $(n=1)$, neurofilament light chain $(\mathrm{n}=1), \operatorname{LUZP} 4(\mathrm{n}=1)$, and unclassified neural antibodies $(n=1)$. Eighteen patients $(64 \%)$ had classical syndromes, and $10(36 \%)$ had nonclassical syndromes (Table 1). Ten patients (36\%) had surgical resection only, 4 (14\%) received cytotoxic chemotherapy or radiation therapy only, and 14 (50\%) underwent resection plus chemotherapy or radiation therapy. Twenty-four patients $(86 \%)$ received immunosuppressant therapies with median modified Rankin Scale score before and after treatment of 3 (IQR, 2-4 before and 1-4 after).

Incidence and prevalence counts are shown in Figure 1, and rates are detailed in Table 2. Twenty-five incident cases were identified from January 1, 1987, to December 31, 2018, and overall incidence was $0.6 / 100,000$ person-years. Incidence was lower in the $1987-2002$ period $(0.4 / 100,000$ person-years $)$ than in the period 2003-2018 (0.8/100,000 person-years; $p=0.06)$. Among 8 prevalent cases on $1 / 1 / 2014$, the prevalence was 5.4/ 100,000 people overall and $11.0 / 100,000$ people for those aged 
Table 1 Clinical Syndromes, Associated Cancers, and Autoantibody Seropositivity; 2004 Paraneoplastic Neurological Syndrome Classification and Paraneoplastic Neurological Syndrome Care Score of the Patients Included in the Study

\begin{tabular}{|c|c|c|c|c|c|}
\hline Patient & Cancer & Syndrome & Antibody & 2004 PNS $^{\mathrm{a}}$ & PNS-Care score ${ }^{b}$ \\
\hline 1 & SCLC & $\begin{array}{l}\text { Rapidly progressive cerebellar } \\
\text { syndrome }^{c}\end{array}$ & ANNA-1 & Definite & 10 \\
\hline 2 & Thymic tumor & Myasthenia gravis & $\operatorname{AchR}^{d}$ & NA & NA \\
\hline 3 & Peritoneal carcinoma & Dermatomyositis & None & Definite & NA \\
\hline 4 & Lymphoma & Limbic encephalitis & None & Definite & 7 \\
\hline 5 & Breast carcinoma & Brainstem encephalitis & ANNA-2 & Definite & 9 \\
\hline 6 & Fallopian tube adenocarcinoma & Rapidly progressive cerebellar syndrome & PCA-1 & Definite & 10 \\
\hline 7 & Seminoma & Limbic encephalitis & KLHL11/LUZP4 & Definite & 9 \\
\hline 8 & Thymic tumor & Myasthenia gravis & AchR & NA & NA \\
\hline 9 & Merkel cell carcinoma & Rapidly progressive cerebellar syndrome & NF-L & Definite & 7 \\
\hline 10 & SCLC & Dermatomyositis & None & Definite & NA \\
\hline 11 & Seminoma & Encephalomyelits & LUZP4 & Definite & 7 \\
\hline 12 & NSCLC & Subacute sensory neuronopathy & None & Definite & 7 \\
\hline 13 & NSCLC & Myasthenia gravis & AchR & NA & NA \\
\hline 14 & Primary peritoneal liposarcoma & $\begin{array}{l}\text { Rapidly progressive cerebellar } \\
\text { syndrome }\end{array}$ & None & Definite & 7 \\
\hline 15 & Breast adenocarcinoma & $\begin{array}{l}\text { Rapidly progressive cerebellar } \\
\text { syndrome }\end{array}$ & UNCA & Definite & 7 \\
\hline 16 & Melanoma & Polyradiculoneuropathy ${ }^{\mathrm{e}}$ & CRMP5/GAD & Definite & 9 \\
\hline 17 & SCLC & Polyradiculoneuropathy & None & Possible & 6 \\
\hline 18 & Breast adenocarcinoma & Dermatomyositis & None & Definite & NA \\
\hline 19 & Urothelial carcinoma & Nonlimbic encephalitis & None & Definite & 6 \\
\hline 20 & Seminoma & $\begin{array}{l}\text { Brainstem encephalitis/rapidly } \\
\text { progressive cerebellar syndrome }\end{array}$ & KLHL11/LUZP4 & Definite & 9 \\
\hline 21 & Thymic tumor & Myasthenia gravis & AchR & NA & NA \\
\hline 22 & Thymic tumor & Limbic encephalitis & CRMP5/LGI1 & Definite & 7 \\
\hline 23 & Thymic tumor & Myasthenia gravis & AchR & NA & NA \\
\hline 24 & Thymic tumor & Myasthenia gravis & AchR & NA & NA \\
\hline 25 & Lymphoma & Rapidly progressive cerebellar syndrome & None & Definite & 7 \\
\hline 26 & Breast adenocarcinoma & Limbic encephalitis & AMPA & Definite & 9 \\
\hline 27 & Seminoma & $\begin{array}{l}\text { Brainstem encephalitis/rapidly } \\
\text { progressive cerebellar syndrome }\end{array}$ & KLHL11/LUZP4 & Definite & 9 \\
\hline 28 & SCLC & Dermatomyositis & None & Definite & NA \\
\hline
\end{tabular}

Abbreviations: AchR = muscle-type acetylcholine receptor binding antibodies (nmol/L); AMPA = a-amino-3-hydroxy-5-methyl-4-isoxazole propionic acid receptor; ANNA-1 = antineuronal nuclear autoantibody type 1 or anti-Hu; ANNA-2 = antineuronal nuclear autoantibody type 1 or anti-Ri; CRMP5 = collapsin response mediator protein 5 or anti-CV2; GAD = glutamic acid decarboxylase; KLH11 = kelch-like protein 11 antibodies; LGI1 = leucine-rich glioma-inactivated protein 1; LUZP4 = leucine zipper 4 antibodies; NA = not applicable; NF-L = neurofilament light chain; NSCLC = non-small-cell lung cancer; $P C A-1=$ Purkinje cell cytoplasmic antibody type 1 or anti-Yo; PNS = paraneoplastic neurologic syndrome; SCLC = small-cell lung cancer; UNCA = unclassified neural antibodies. a 2004 paraneoplastic neurologic syndrome criteria classification, subdivided into definite or possible classification. ${ }^{10}$

b 2021 Graus updated paraneoplastic neurologic syndrome criteria classification classified as definite (score $\geq 8$ ), probable (score 6-7), or possible (4-5). ${ }^{9}$

${ }^{\mathrm{c}}$ Rapidly progressive cerebellar syndrome, formerly subacute cerebellar degeneration.

a Muscle-type acetylcholine receptor binding antibodies were not included in analysis of incidence/prevalence by antibody subtype or required for clinical diagnosis.

e Polyradiculoneuropathy per updated 2021 classification, encompassing what was formerly described as a nonclassical syndrome autonomic neuropathy. 
Table 2 Age- and Sex-Adjusted Prevalence and Incidence Rates for Paraneoplastic Neurologic Syndrome in Olmsted County, Minnesota

\begin{tabular}{|c|c|c|c|c|}
\hline & $\mathbf{N}$ & $\begin{array}{l}\text { Incidence } \\
\text { (per 100,000 } \\
\text { person-years) }^{\mathrm{a}} \\
1987-2018^{\mathrm{c}}\end{array}$ & $\mathbf{N}$ & $\begin{array}{l}\begin{array}{l}\text { Prevalence } \\
(\text { per } 100,000 \\
\text { population }^{\mathrm{b}}\end{array} \\
\text { January } 1,2014^{\mathrm{c}}\end{array}$ \\
\hline All cases & 25 & 0.6 & 8 & 5.4 \\
\hline Cases excluding dermatomyositis & 21 & 0.5 & 8 & 5.4 \\
\hline \multicolumn{5}{|l|}{ Sex } \\
\hline Male & 12 & 0.6 & 5 & 7.0 \\
\hline Female & 13 & 0.6 & 3 & 3.4 \\
\hline \multicolumn{5}{|l|}{ Age group } \\
\hline$>60 y$ & 11 & 1.7 & 3 & 11.0 \\
\hline $18-60 y$ & 14 & 0.6 & 5 & 5.6 \\
\hline \multicolumn{5}{|l|}{ Race and ethnicity } \\
\hline Asian & 1 & 1.3 & 0 & - \\
\hline Black or African American & 2 & 1.2 & 0 & - \\
\hline Non-Hispanic White & 21 & 0.6 & 8 & 6.7 \\
\hline Hispanic & 1 & 0.5 & 0 & - \\
\hline \multicolumn{5}{|l|}{ Principal syndrome ${ }^{d}$} \\
\hline Rapidly progressive cerebellar syndrome & 8 & 0.2 & 1 & 0.7 \\
\hline Myasthenia gravis & 5 & 0.1 & 2 & 1.4 \\
\hline Any encephalitis & 4 & 0.1 & 4 & 2.7 \\
\hline Limbic encephalitis & 3 & 0.1 & 2 & 1.4 \\
\hline Brainstem encephalitis & 1 & 0.03 & 1 & 0.6 \\
\hline Nonlimbic encephalitis & 0 & - & 1 & 0.6 \\
\hline Dermatomyositis & 4 & 0.1 & 0 & - \\
\hline Polyradiculoneuropathy & 2 & 0.1 & 0 & - \\
\hline Subacute sensory neuronopathy & 1 & 0.03 & 1 & 0.6 \\
\hline Encephalomyelitis & 1 & 0.02 & 0 & - \\
\hline \multicolumn{5}{|l|}{ Cancer type $e^{e, f}$} \\
\hline Seminoma & 4 & 0.2 & 2 & 2.8 \\
\hline Breast adenocarcinoma & 4 & 0.2 & 1 & 1.3 \\
\hline Lung small-cell carcinoma & 4 & 0.1 & 0 & - \\
\hline Thymic tumor & 4 & 0.1 & 3 & 2.1 \\
\hline Fallopian tubal adenocarcinoma & 1 & 0.05 & 0 & - \\
\hline Lymphoma & 2 & 0.05 & 0 & - \\
\hline Lung non-small-cell carcinoma & 2 & 0.05 & 1 & 0.6 \\
\hline Primary peritoneal carcinoma/liposarcoma & 2 & 0.04 & 0 & - \\
\hline Merkel cell carcinoma & 1 & 0.03 & 0 & - \\
\hline Melanoma & 1 & 0.03 & 0 & - \\
\hline Urothelial carcinoma & 0 & - & 1 & 0.6 \\
\hline
\end{tabular}


Table 2 Age- and Sex-Adjusted Prevalence and Incidence Rates for Paraneoplastic Neurologic Syndrome in Olmsted County, Minnesota (continued)

\begin{tabular}{l}
\hline Nence \\
\hline Neural autoantibody positivity \\
\hline Yes \\
\hline No
\end{tabular}

$>60$ years. After excluding dermatomyositis, the incidence remained roughly similar at $0.5 / 100,000$ person-years, and the prevalence remained 5.4/100,000 person-years. Thymic tumors were identified most commonly, but seminoma incidence was highest (0.2/100,000 person-years; prevalence 2.8/100,000 people). Incidence rates for the most commonly reported PNS: rapidly progressive cerebellar syndrome $0.2 / 100,000$ personyears; dermatomyositis $0.1 / 100,000$ person-years; and limbic encephalitis $0.1 / 100,000$ person-years. Among high risk paraneoplastic antibodies, kelch-like protein $11 \mathrm{IgG}$ had the highest

Figure 2 Disability-Adjusted Life Years Estimated for Each Patient in the Paraneoplastic Neurologic Syndrome (PNS) Cohort

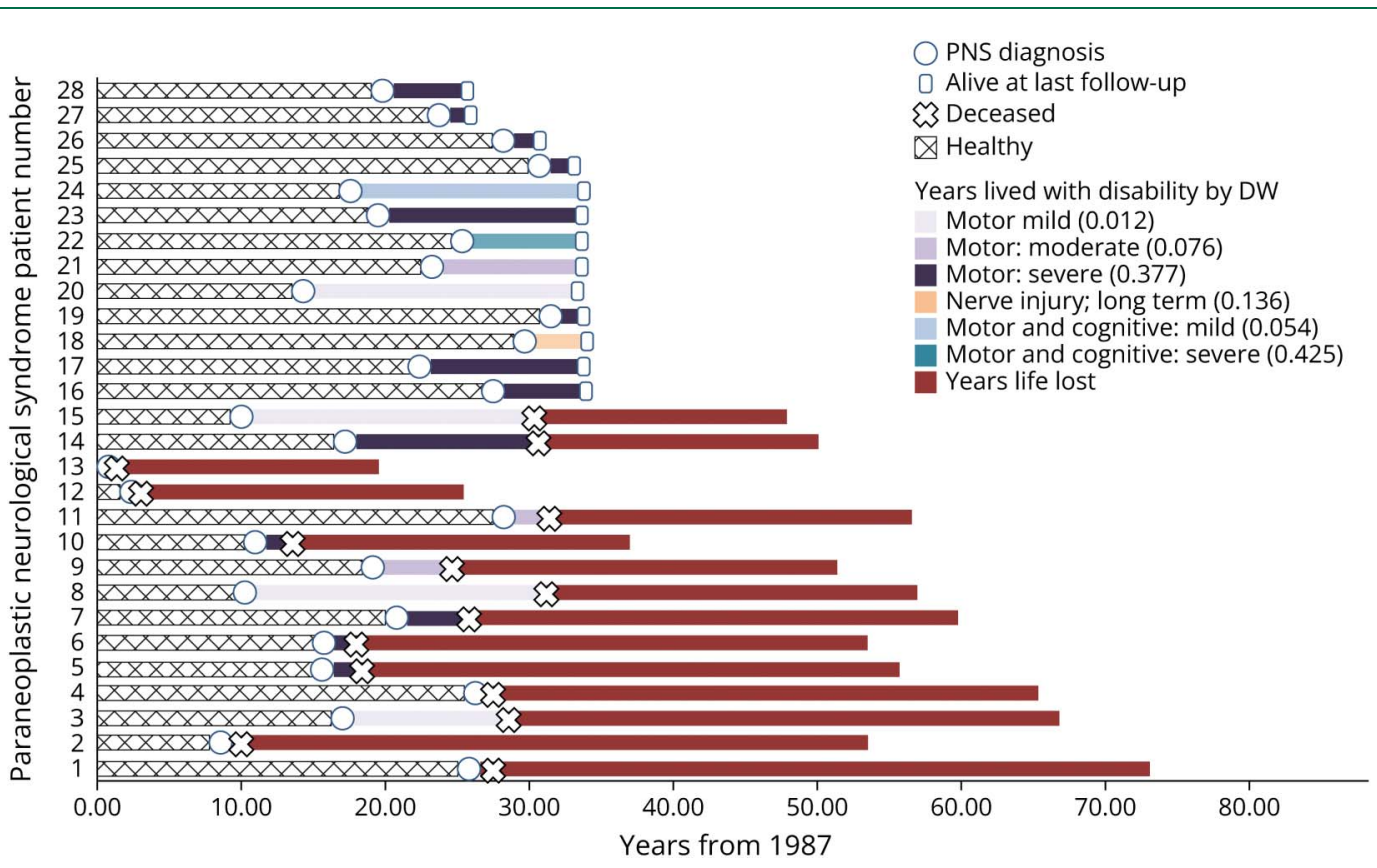

Years of follow-up from 1987 for 28 patients. Time from 1987 to diagnosis, time patients lived with disability specified by disability weight, time to death, and years of life lost are shown. The years lived with disability shown in the figure is calculated as the years from PNS diagnosis to follow-up multiplied by the patient-specific disability weight. Disability weights used for each patient as described by the World Health Organization Global Burden of Disease, chosen for each patient based on each patient's principal neurologic disability (motor impairment: mild, moderate, and severe; motor and cognitive impairment: mild, moderate, and severe; and nerve injury: long term for 2 patients with autonomic dysfunction). 
incidence at $0.1 / 100,000$ person-years and prevalence of 1.4 / 100,000 people.

The median follow-up period after PNS diagnosis was 3.1 years (IQR, 1.1-9.9 years). At last follow-up, 8/28 patients (29\%) were wheelchair users; 15 (54\%) were dead at the study period's end (the median interval from diagnosis to death was 2.0 years [IQR $0.4-10.8$ years]). Total disability-adjusted life years (DALYs) for 28 patients with PNS were 472.7 years, based on total years of life lost (YLL) for patients dying between 1987 and $2018(\mathrm{n}=15)$ of 445.3 years plus years lived with disability (YLD) 27.4 years. Median DALYs were 17.1 (range 0.0-46.4), median YLL were 26.0 (range 15.2-46.3), and median YLD were 0.4 (range 0.0-4.9) with individual DALYs in Figure 2.

\section{Discussion}

PNSs are rare neurologic disorders but are associated with severe morbidity and mortality. We estimated a prevalence of 5.4 cases per 100,000 people, which is approximately half the prevalence of autoimmune encephalitis $(13.7 / 100,000)$ and infectious encephalitides $(11.6 / 100,000)$ and comparable to neuromyelitis optica spectrum disorder $(3.9 / 100,000)$ in Olmsted County. ${ }^{7,14}$ The incidence of 0.6 per 100,000 persons per year was slightly lower than the incidence of autoimmune encephalitis $(0.8 / 100,000)$ and infectious encephalitides (1.0/ $100,000)$ in Olmsted County, but was higher than neuromyelitis optica spectrum disorder $(0.7 / 100,000)$ in the same population. Extrapolating from Olmsted County results to the US population on January 1, $2014(317,243,472)$, we estimated a national PNS prevalence of approximately 17,099 cases. $^{15}$

The doubled incidence of PNS between 1987-2002 and 2003-2018 is likely attributable to the increasing recognition of new neural autoantibody markers aiding diagnosis and improved disease classification. This mirrors similar trends reported in epidemiologic studies of autoimmune encephalitis and other PNS epidemiologic studies. ${ }^{2,3,7}$ Immune checkpoint inhibitor therapies enhance antitumor immunity but induce off-target autoimmune complications, including neurologic autoimmunity (both classical and nonclassical PNS) ${ }^{16,17}$ Increased application of these therapies to cancers (especially small-cell lung carcinoma) can be anticipated to increase the frequency of PNS. ${ }^{18}$

The rarity of PNS belies their significant mortality and morbidity burden and has important implications for resource allocation and health care planning. Indeed, the predicted DALY for all USA cases, based on the median value from the Olmsted County PNS cases, is 292,393. In contrast, the 2014 estimated DALY for amyotrophic lateral sclerosis was 197,619 (largely years of life lost), and for multiple sclerosis was 201,091 (largely years lived with disability); both DALY estimates increased only slightly through $2017 .{ }^{19}$

As previously recognized, ${ }^{2,3}$ the most frequent PNS were rapidly progressive cerebellar syndrome, myasthenia gravis, dermatomyositis, and limbic encephalitis, mostly associated with thymic, breast, and neuroendocrine (small-cell lung/ Merkel cell) neoplasms. The overrepresentation of seminoma in the more recent Olmsted County study period may reflect recent recognition of novel neural autoantibody markers of this neoplasm such as KLH11 and LUZP4 and contrasts with prior reports suggesting that small-cell lung, breast, and ovarian cancers were most commonly identified in PNS in association with ANNA-1 and PCA-1. ${ }^{20-22}$ By using the validated, entirely enumerated medical record linkage system of the REP in a smaller geographically defined region of the United States, we believe that we were able to accurately capture the number of patients with PNS in the region. ${ }^{4}$ It is not surprising that due to these differences, as well as the exclusion of dermatomyositis, there were considerably lower incidence rates extrapolated from data at a major paraneoplastic serologic testing and patient referral center in France. ${ }^{3}$ A similar study of definite PNS, which also included dermatomyositis, from a major testing center for several provinces in Italy, reported slightly lower prevalence rates but higher incidence rates. ${ }^{2}$ This difference may also be due to important differences in the case identification methodology, differences in region-dependent disease recognition and reporting, and the significantly higher proportion of antibody-negative patients in this cohort. ${ }^{2,3}$ Alternatively, the different findings may reflect regional differences in PNS incidence and prevalence requiring further exploration into contributing factors such as age, sex, or race. ${ }^{3}$ Strengths of our study include the capture of medical records for the complete population of Olmsted County, Minnesota, inclusion of the 2021 updated PNS criteria and uniform autoimmune serologic testing by a single laboratory with the ability to retest known cases of PNS for novel autoantibodies. ${ }^{1,4,16}$ Limitations of our study include the smaller size of the Olmsted County population preventing detection of PNS associated with less frequently detected neural antibodies and the exclusion of possible PNS by diagnostic criteria, thereby restricting eligible patients. ${ }^{9}$ Furthermore, small number of prevalent or incident PNS cases limits epidemiologic assessment of individual neural specific antibodies. Natural history of PNS vary in part due to different combinations of cancer (seminoma vs small-cell lung cancer) and neurologic disease-associated mortality (encephalomyelitis vs polyradiculoneuropathy), which may result in an underestimation of the prevalence when only considering a single point in time.

As of the early 2000s, Olmsted County has resembled the state of Minnesota and the upper Midwest with comparable median age ( 35.0 vs 35.4 years vs 35.9$)$, the percentage of men in the population ( $49.1 \%$ vs $49.5 \%$ vs $49.4 \%$ ), and the percentage of population that is ethnically White ( $90.3 \%$ vs $89.4 \%$ vs $90.2 \%$ ). The median age ( 35.0 vs 35.3 ) and percentage male ( $49.1 \%$ vs 49.1\%) distribution of the county resemble the entire US population but differ when comparing percentage White ethnicity ( $90.3 \%$ vs $75.1 \%$ ), a reflection of the lower percentage of primarily African American and Hispanic or Latino populations in Olmsted County. Olmsted County is less ethnically diverse than the United States overall but between 1970 and 2000 
shifted from $99.1 \%$ White to $90.3 \%$ White. ${ }^{23}$ Comparison of REP data to Minnesota and upper Midwest census data suggests that the results are generalizable to these regions and cautiously generalizable to the entire United States, which we suspect would be possible with our cohort due to the severe nature of PNS necessitating in-person evaluation by a neurologist and the increased local and national recognition of these disorders. ${ }^{23}$ Our study, a report of the incidence and prevalence of PNS in North America, provides robust epidemiologic data with reference to cancer and syndrome and uses a populationbased records linkage system which captures the entire population of Olmsted County. ${ }^{4}$

\section{Acknowledgment}

The authors acknowledge the support of the Mayo Clinic Center for Multiple Sclerosis and Autoimmune Neurology.

\section{Study Funding}

No targeted funding reported.

\section{Disclosure}

S. Shah, E.P. Flanagan, P. Paul, C.Y. Smith, S.C. Bryant, and M. F. Devine report no disclosures relevant to the manuscript. V.A. Lennon shares in royalties derived from sale of aquaporin-4-IgG testing and has patents pending for KLHL11, LUZP4-IgG, Septins 5 and 7, PDE10A and MAP1B as markers of neurological autoimmunity and paraneoplastic disorders. A. McKeon has patents pending for KLHL11, LUZP4-IgG, Septins 5 and 7, PDE10A and MAP1B as markers of neurological autoimmunity and paraneoplastic disorders. S.J. Pittock is a named inventor on filed patents that relate to functional AQP4/NMO-IgG assays and NMO-IgG as a cancer marker. He has a patent pending for Septin 5, MAP1B IgG, KLHL11-IgG and LUZP4-IgG as markers of neurological autoimmunity and paraneoplastic disorders. D. Dubey has a patent pending for KLHL11-IgG and LUZP4-IgG as markers of neurological autoimmunity. Go to Neurology.org/NN for full disclosures.

\section{Publication History}

Received by Neurology: Neuroimmunology \& Neuroinflammation August 17, 2021. Accepted in final form November 15, 2021.

Appendix Authors

\begin{tabular}{lll}
\hline Name & Location & Contribution \\
\hline $\begin{array}{l}\text { Shailee } \\
\text { Shah, MD }\end{array}$ & Department of Neurology, & Mayo Clinic, Rochester, MN \\
& & $\begin{array}{l}\text { Drafting/revision of the } \\
\text { manuscript for content, } \\
\text { including medical writing for } \\
\text { content; major role in the } \\
\text { acquisition of data; and } \\
\text { analysis or interpretation of } \\
\text { data }\end{array}$
\end{tabular}

\begin{tabular}{lll}
\hline Eoin P. & Department of Neurology, & $\begin{array}{l}\text { Drafting/revision of the } \\
\text { Flanagan, }\end{array}$ \\
MBBCh & $\begin{array}{l}\text { Mayo Clinic, Rochester, MN; } \\
\text { Department of Laboratory } \\
\text { Medicine and Pathology, }\end{array}$ & $\begin{array}{l}\text { including medical writing for } \\
\text { content; and major role in the } \\
\text { acquisition of data }\end{array}$ \\
& $\begin{array}{l}\text { Mayo Clinic College of } \\
\text { Medicine, Rochester, MN }\end{array}$ & \\
\hline
\end{tabular}

Appendix (continued)

\begin{tabular}{lll}
\hline Name & Location & Contribution \\
\hline $\begin{array}{l}\text { Pritikanta } \\
\text { Paul, MD }\end{array}$ & $\begin{array}{l}\text { Department of Neurology, } \\
\text { Mayo Clinic, Rochester, MN }\end{array}$ & $\begin{array}{l}\text { Major role in the acquisition } \\
\text { of data and analysis or } \\
\text { interpretation of data }\end{array}$ \\
\hline $\begin{array}{l}\text { Carin Y. } \\
\text { Smith, BS }\end{array}$ & $\begin{array}{l}\text { Department of Quantitative } \\
\text { Health Sciences, Mayo Clinic, } \\
\text { Rochester, MN }\end{array}$ & $\begin{array}{l}\text { Major role in the acquisition } \\
\text { of data and analysis or } \\
\text { interpretation of data }\end{array}$ \\
\hline
\end{tabular}

Sandra C. Department of Quantitative Major role in the acquisition

Bryant, MS Health Sciences, Mayo Clinic, of data and analysis or Rochester, MN interpretation of data

\begin{tabular}{lll}
\hline Michelle F. & Department of Neurology, & Drafting/revision of the \\
Devine, & Mayo Clinic, Rochester, MN; & $\begin{array}{l}\text { manuscript for content, } \\
\text { including medical writing for }\end{array}$ \\
MD & Olmsted Medical Center, & $\begin{array}{l}\text { content } \\
\text { Rochester, MN }\end{array}$
\end{tabular}

Vanda A. Department of Neurology Drafting/revision of the

Lennon, and Department of manuscript for content,

MD, PhD Immunology, Mayo Clinic, including medical writing for Rochester, MN; Department content of Laboratory Medicine and Pathology, Mayo Clinic College of Medicine,

Rochester, $\mathrm{MN}$;

\begin{tabular}{|c|c|c|}
\hline $\begin{array}{l}\text { Andrew } \\
\text { McKeon, } \\
\text { MD }\end{array}$ & $\begin{array}{l}\text { Department of Neurology, } \\
\text { Mayo Clinic, Rochester, MN; } \\
\text { Department of Laboratory } \\
\text { Medicine and Pathology, } \\
\text { Mayo Clinic College of } \\
\text { Medicine, Rochester, MN }\end{array}$ & $\begin{array}{l}\text { Drafting/revision of the } \\
\text { manuscript for content, } \\
\text { including medical writing for } \\
\text { content }\end{array}$ \\
\hline $\begin{array}{l}\text { Sean J. } \\
\text { Pittock, } \\
\text { MD }\end{array}$ & $\begin{array}{l}\text { Department of Neurology, } \\
\text { Mayo Clinic, Rochester, MN; } \\
\text { Department of Laboratory } \\
\text { Medicine and Pathology, } \\
\text { Mayo Clinic College of } \\
\text { Medicine, Rochester, MN }\end{array}$ & $\begin{array}{l}\text { Drafting/revision of the } \\
\text { manuscript for content, } \\
\text { including medical writing for } \\
\text { content }\end{array}$ \\
\hline $\begin{array}{l}\text { Divyanshu } \\
\text { Dubey, MD }\end{array}$ & $\begin{array}{l}\text { Department of Neurology, } \\
\text { Mayo Clinic, Rochester, MN; } \\
\text { Department of Laboratory } \\
\text { Medicine and Pathology, } \\
\text { Mayo Clinic College of } \\
\text { Medicine, Rochester, MN }\end{array}$ & $\begin{array}{l}\text { Drafting/revision of the } \\
\text { manuscript for content, } \\
\text { including medical writing for } \\
\text { content; major role in the } \\
\text { acquisition of data; study } \\
\text { concept or design; analysis or } \\
\text { interpretation of data; and } \\
\text { study supervision }\end{array}$ \\
\hline
\end{tabular}

\section{References}

1. Darnell RB, Posner JB. Paraneoplastic syndromes involving the nervous system. N Engl J Med 2003;349(16):1543-1554.

2. Vogrig A, Gigli GL, Segatti S, et al. Epidemiology of paraneoplastic neurological syndromes: a population-based study. J Neurol 2020;267(1):26-35.

3. Hébert J, Riche B, Vogrig A, et al. Epidemiology of paraneoplastic neurologic syndromes and autoimmune encephalitides in France. Neurol Neuroimmunol Neuroinflamm 2020;7(6):e883.

4. St Sauver JL, Grossardt BR, Yawn BP, Melton LJ III, Rocca WA. Use of a medical records linkage system to enumerate a dynamic population over time: the Rochester epidemiology project. Am J Epidemiol 2011;173(9):1059-1068.

5. Rocca WA, Yawn BP, St Sauver JL, Grossardt BR, Melton LJ III. History of the Rochester epidemiology project: half a century of medical records linkage in a US population. Mayo Clin Proc 2012;87(12):1202-1213.

6. St Sauver JL, Grossardt BR, Yawn BP, et al. Data resource profile: the Rochester epidemiology project (REP) medical records-linkage system. Int J Epidemiol 2012; 41(6):1614-1624.

7. Dubey D, Pittock SJ, Kelly CR, et al. Autoimmune encephalitis epidemiology and a comparison to infectious encephalitis. Ann Neurol 2018;83(1):166-177.

8. Budhram A, Dubey D, Sechi E, et al. Neural antibody testing in patients with suspected autoimmune encephalitis. Clin Chem 2020;22:1496-1509.

9. Graus F, Vogrig A, Muniz-Castrillo S, et al. Updated diagnostic criteria for paraneoplastic neurologic syndromes. Neurol Neuroimmunol Neuroinflamm 2021;8(4):e1014.

10. Graus F, Delattre JY, Antoine JC, et al. Recommended diagnostic criteria for paraneoplastic neurological syndromes. J Neurol Neurosurg Psychiatry 2004;75(8): $1135-1140$. 
11. Schroeder SA. Incidence, prevalence, and hybrid approaches to calculating disabilityadjusted life years. Popul Health Metr 2012;10(1):19.

12. World Health Organization. WHO Methods and Data Sources for Global Burden of Disease Estimates 2000-2011. 2013. Accessed December 17, 2021. https://www.who. int/healthinfo/statistics/GlobalDALYmethods_2000_2011.pdf

13. Salomon JA, Haagsma JA, Davis A, et al. Disability weights for the global burden of disease 2013 study. Lancet Glob Health 2015;3(11):e712-23.

14. Flanagan EP, Cabre P, Weinshenker BG, et al. Epidemiology of aquaporin-4 autoimmunity and neuromyelitis optica spectrum. Ann Neurol 2016;79(5):775-783.

15. National Population by Characteristics: 2010-2019. Monthly Postcensal Resident Population. 2019. author is "US Census Bureau" https://www.census.gov/data/tables/time-series/demo/popest/2010s-national-detail.html

16. Dubey D, David WS, Reynolds KL, et al. Severe neurological toxicity of immune checkpoint inhibitors: growing spectrum. Ann Neurol 2020;87(5):659-669.

17. Guidon AC, Burton LB, Chwalisz BK, et al. Consensus disease definitions for neurologic immune-related adverse events of immune checkpoint inhibitors. J Immunother Cancer 2021;9(7):e002890
18. Horn L, Mansfield AS, Szczesna A, et al. First-line atezolizumab plus chemotherapy in extensive-stage small-cell lung cancer. N Engl J Med 2018;379(23): 2220-2229.

19. Collaborators GUND: Feigin VL, Vos T, et al. Burden of neurological disorders across the US from 1990-2017: a global burden of disease study. JAMA Neurol 2021;78(2): 165-176.

20. Dubey D, Kryzer T, Guo Y, et al. Leucine zipper 4 autoantibody: a novel germ cell tumor and paraneoplastic biomarker. Ann Neurol 2021;89(5):1001-1010.

21. Dubey D, Wilson MR, Clarkson B, et al. Expanded clinical phenotype, oncological associations, and immunopathologic insights of paraneoplastic Kelch-like protein-11 encephalitis. JAMA Neurol 2020;77(11):1420-1429.

22. Giometto B, Grisold W, Vitaliani R, Graus F, Honnorat J, Bertolini G. Paraneoplastic neurologic syndrome in the PNS Euronetwork database: a European study from 20 centers. Arch Neurol 2010;67(3):330-335.

23. St Sauver JL, Grossardt BR, Leibson CL, Yawn BP, Melton LJ 3rd, Rocca WA. Generalizability of epidemiological findings and public health decisions: an illustration from the Rochester epidemiology project. Mayo Clin Proc 2012;87(2):151-160. 


\section{Neurology \\ Neuroimmunology \& Neuroinflammation}

\section{Population-Based Epidemiology Study of Paraneoplastic Neurologic Syndromes Shailee Shah, Eoin P. Flanagan, Pritikanta Paul, et al. Neurol Neuroimmunol Neuroinflamm 2022;9; DOI 10.1212/NXI.0000000000001124}

This information is current as of December 22, 2021

\section{Updated Information \& Services}

References

Subspecialty Collections

Permissions \& Licensing

Reprints including high resolution figures, can be found at: http://nn.neurology.org/content/9/2/e1124.full.html

This article cites 21 articles, 4 of which you can access for free at: http://nn.neurology.org/content/9/2/e1124.full.html\#\#ref-list-1

This article, along with others on similar topics, appears in the following collection(s):

Autoimmune diseases

http://nn.neurology.org//cgi/collection/autoimmune_diseases

Incidence studies

http://nn.neurology.org//cgi/collection/incidence_studies

Paraneoplastic syndrome

http://nn.neurology.org//cgi/collection/paraneoplastic_syndrome Prevalence studies

http://nn.neurology.org//cgi/collection/prevalence_studies

Information about reproducing this article in parts (figures,tables) or in its entirety can be found online at:

http://nn.neurology.org/misc/about.xhtml\#permissions

Information about ordering reprints can be found online: http://nn.neurology.org/misc/addir.xhtml\#reprintsus

Neurol Neuroimmunol Neuroinflamm is an official journal of the American Academy of Neurology.

Published since April 2014, it is an open-access, online-only, continuous publication journal. Copyright Copyright $\left({ }^{\circ} 2021\right.$ The Author(s). Published by Wolters Kluwer Health, Inc. on behalf of the American Academy of Neurology.. All rights reserved. Online ISSN: 2332-7812.

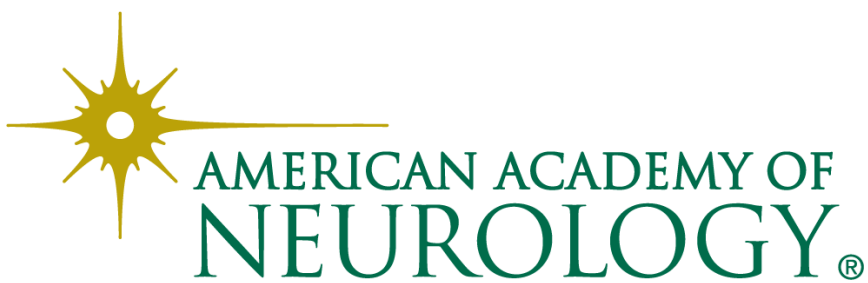

